\title{
„Tu dokonało się zwycięstwo nad potężnym, zwartym łańcuchem Alp"*. Semmering w przewodnikach między 1852 a 1873 rokiem
}

\author{
https://doi.org/10.19195/2084-4107.14.9
}

Od połowy XIX wieku kolej zmienia krajobraz Europy, wytyczając trasy, wcinając się w skały i drążąc tunele, tworząc wiadukty i nasypy. Nowy sposób podróżowania wpływa też na postrzeganie krajobrazu. Szyny kolejowe odbierają podróżnym bezpośredni kontakt z terenem. Między podróżującym a krajobrazem znajduje się teraz maszynowy ansambl kolei ${ }^{1}$. Prędkość, z którą przemierza się krajobraz, ogranicza widzenie, powstaje nowy sposób postrzegania. Pierwszy plan traci na znaczeniu, a wciąż zmieniające się perspektywy zlewają się w kolejnych scenach $w$ panoramy ${ }^{2}$. Spojrzenie przez okno jadącego pociągu po raz pierwszy dało możliwość takiego sposobu postrzegania ${ }^{3}$.

Pierwszą wysokogórską kolej świata poprowadzono w latach 1848-1854 przez Semmering, region wschodniej odnogi Alp położony około 70 kilometrów na południe od Wiednia. Aby parowa lokomotywa mogła ujarzmić górską topografię, zbudowano pod kierunkiem inżyniera Carla Rittera von Ghega 16 wiaduktów oraz 15 tuneli. Linia kolejowa Semmering zaczęła działać w 1854 roku i od tego czasu jest częścią jednej z głównych linii kolei austriackiej. Od roku 1880 w otoczeniu przełęczy Semmering zaczęło się rozwijać letnisko. Przede wszystkim wiedeńskie towarzystwo odkryło dla siebie piękno tego górskiego krajobrazu, zbudowano kolonię willi i pierwsze grandhotele. W roku 1998 linia kolejowa Semmering została wpisana jako pierwsza na świecie linia kolejowa na listę światowego dziedzictwa UNESCO.

Budowa linii kolejowej, a także rozwój letniska zostały wyczerpująco opracowane pod kątem badawczym. Centrum niniejszych badań jest natomiast całkowicie na nowo ukształtowany przez budowę linii kolejowej Semmering krajobraz w okresie od czasów budowy linii po początek lat osiemdziesiątych XIX wieku, kiedy to przełęcz Semmering została odkryta jako letnisko przez społeczność miejską. Jak postrzegano Semmering, zanim odkryta została przez wiedeńskie towarzystwo jako region letniskowy? Jak te potężne zmiany, które dokonały się w krajobrazie alpejskim w wyniku budowy kolei, przedstawiano w ówczesnych przewodnikach?

* A. Mandl, J.G. Seidl, Die Staatsbahn von Wien bis Triest mit ihren Umgebungen, Triest 1856, s. 99.

${ }^{1}$ W. Schivelbusch, Geschichte der Eisenbahnreise: Zur Industrialisierung von Raum und Zeit im 19. Jahrhundert, Frankfurt a. M. 2007, s. 27.

2 Ibidem, s. 61.

3 D. Speich, Rechts und Links der Eisenbahn: Zur visuellen Standardisierung der touristischen Eisenbahnfahrt, [w:] Die Internationalität der Eisenbahn 1850-1970, red. M. Burri, K.T. Elsasser, D. Gugerli, Zürich 2003, s. 96. 


\section{Jakościowa analiza treści}

Już w czasach przedindustrialnych istniały drukowane przewodniki, które wraz z pojawieniem się kolei żelaznej zyskały szczególne znaczenie. Kierowały one postrzeganiem z jadącego pociągu, a tym samym stały się częścią składową nowej infrastruktury ${ }^{4}$.

Od połowy XIX wieku w handlu pojawiały się w dużej liczbie przewodniki dopasowane specjalnie do potrzeb podróży koleją żelazną. [...] Przewodniki ułatwiały tworzenie struktury odniesień do zewnętrznej przestrzeni, podsuwając właściwe punkty oparcia dla wzroku, a także wizualne choreografie dla widoku z okna pociągu ${ }^{5}$.

Niniejszy artykuł opiera się na jakościowej analizie według Mayringa ${ }^{6}$. Przebadane źródła pokrywają okres od budowy linii kolejowej Semmering (1848-1854) do odkrycia regionu jako miejscowości letniskowej (1879) ${ }^{7}$. Podstawę wyboru źródeł stworzyła obszerna bibliografia literatury dotyczącej linii kolejowej Semmering 8 . Wprawdzie możliwości noclegowe dla turystów powstawały na przełęczy Semmering dopiero od lat osiemdziesiątych XIX wieku, lecz już w czasach budowy dostępne były pierwsze przewodniki. Z 17 dostępnych przewodników z całego okresu, którego dotyczą badania, do dalszego opracowania po wstępnej lekturze wybrano siedem głównych źródeł, kierując się ich treścią w odniesieniu do interesujących kwestii badawczych. Źródła z okresu 1852-1873 zostały uporządkowane chronologicznie i podzielone na dwie grupy: przewodniki dotyczące budowy i przewodniki dotyczące kolei. Opisy z perspektywy pociągu zajmują szczególną pozycję. W wypadku dwóch spośród wybranych źródeł mamy do czynienia z gruntownie zmienionymi nowymi wydaniami.

Przewodniki dotyczące budowy pochodzą z roku 1852, ukazały się w czwartym roku budowy (1848-1854). Der Führer über den Semmering (Przewodnik po Semmering) Andreasa Schuhmachera ${ }^{9}$ i Der Tourist auf der Südbahn (Turysta na kolei południowej) Franza Weidmanna ${ }^{10}$ relacjonują, dając odczucie realizmu, wysadzanie skał, opisują masy żwiru, zasypane drogi i miejsca, w których mieszkali robotnicy. Momentami autorzy ukazują czytelnikowi perspek-

4 Ibidem, s. 93.

5 Ibidem, s. 100.

6 Ph. Mayring, Qualitative Inhaltsanalyse: Grundlagen und Techniken, Weinheim-Basel 2015.

7 Wtedy to pewne konsorcjum nabyło grunt na Semmering, co stało się punktem wyjścia rozwoju turystyki. M. Schwarz, Stilfragen der Semmeringarchitektur (2), [w:] Die Eroberung der Landschaft: Semmering - Rax - Schneeberg, red. W. Kos, Wien 1992, s. 567.

8 B. Neuner, Bibliographie der Semmeringbahn-Literatur, Mürzzuschlag 2017.

9 A. Schuhmacher, Der Führer über den Semmering. Vollständige Beschreibung der Naturund Kunstwunder auf der Eisenbahn von Gloggnitz bis Mürzzuschlag, Wien 1852.

10 F.C. Weidmann, Der Tourist auf der Südbahn von Wien bis Triest, Wien 1852. 
tywę z niedokończonej trasy kolejowej, tak jakby już siedziało się w pociągu. Der Führer über den Semmering ukazał się już w 1853 roku jako drugie wydanie ${ }^{11}$ i został uwzględniony w analizie. Porównanie obu wydań wyraźnie uwidacznia postęp prac budowlanych.

Drugą, i większą, grupę badanych tekstów tworzą przewodniki dotyczące kolei. August Mandl i Johann Gabriel Seidl wydali w roku 1856, dwa lata po ukończeniu budowy linii kolejowej Semmering, przewodnik Die Staatsbahn von Wien bis Triest (Kolej Państwowa od Wiednia do Triestu) ${ }^{12}$. Przewodnik składa się z trzech części, w których opisana została trasa kolejowa z Wiednia do Triestu wraz z osadami i miastami w jej okolicy. Przełęczy Semmering poświęcona jest cała część druga.

Po śmierci Franza Carla Weidmanna (1867) wydawnictwo Carl Gerold's Sohn powierzyło rewizję przewodnika Der Tourist auf der Südbahn Theodorowi Gettingerowi ${ }^{13}$. Wprowadzające gruntowne zmiany nowe opracowanie ukazało się w 1868 roku, będąc reakcją na sytuację, która całkowicie się zmieniła od czasu budowy. Gettinger nadał tekstowi nową strukturę, opisując najpierw podróż koleją z Wiednia do Triestu, a następnie wycieczki z poszczególnych stacji14.

W 1858 roku W.A. Julius wydał przewodnik Semmering und Reichenau ${ }^{15}$. Przewodnik ten daje wskazówki odnoszące się do jedno- lub dwudniowego pobytu. Poczynając od dworca południowego w Wiedniu, opisywane są ciekawostki wzdłuż trasy, przy czym punktem wyjścia opisów są poszczególne stacje. Przed częścią poświęconą linii kolejowej na Semmering znajduje się opis historii jej budowy. Następnie pojawia się opis z perspektywy pociągu, w którym nazwane zostają poszczególne elementy krajobrazu.

W 1873 roku Rafael Hellbach wydał przewodnik Der kundige Begleiter auf den Semmeringfahrten (Wytrawny towarzysz w podróżach na Semmering) ${ }^{16}$. Odniósł się on do kursujących w miesiącach letnich tak zwanych pociągów rozrywkowych. Opis podróży znowu odbywa się z perspektywy pociągu, pojawia się na początku przewodnika, który w dalszej części zawiera wskazówki odnoszące się do wycieczek od jednego do trzech dni.

Historyczne ilustracje szczególnie dobitnie ukazują przemianę krajobrazu w następstwie wybudowania kolei. Uzupełniają one artykuł, ukazując ingerencje w topografię oraz uzupełnienie trasy tunelami i wiaduktami.

11 A. Schuhmacher, Der Führer über den Semmering. Vollständige Beschreibung der Naturund Kunstwunder auf der Eisenbahn von Gloggnitz bis Mürzzuschlag, sammt Ausflügen in die Umgebungen ..., Wien 1853.

12 A. Mandl, J.G. Seidl, op. cit.

13 F.C. Weidmann, T. Gettinger, Der Tourist auf der Südbahn von Wien bis Triest, Wien 1868.

14 Ibidem.

15 W.A. Julius, Semmering und Reichenau: Führer für 1 oder 2 Tage, Wien 1858.

16 R. Hellbach, Der kundige Begleiter auf den Semmeringfahrten, Wien 1873. 


\section{Kodowanie i weryfikacja}

W odniesieniu do pytania o postrzeganie krajobrazu w pierwszych latach linii kolejowej na Semmering stworzono, w celu dokonania jakościowej analizy treści, system kategorii jako raster, tak aby pozyskać z tekstów istotne dla badania aspekty. Kategorie powstały z kombinacji procedur dedukcyjnych i indukcyjnych. W pierwszej fazie w wyniku dedukcji ustalono kategorie i przetestowano je w części tekstów przez kodowanie. Ta faza pozwoliła na doprecyzowanie podziału na kategorie i częściowe ich uzupełnienie na drodze indukcji. Następnie w procesie indukcyjnym stworzono podkategorie. Na przykład odnośnie do ustalonej w dedukcji kategorii ,budowle inżynierskie"17 wyekstrahowano z tekstów, stosując indukcję, następujące podkategorie: Schwarza Viadukt, Weinzettelwand, Krauselklause, Pollereswand Tunnel, Kalte Rinne Viadukt, Adlitzgraben Viadukt, Haupttunnel. Ustalone w ten sposób kategorie i podkategorie zostały zastosowane do kodowania głównych źródeł.

\section{Budowle inżynierskie}

Schwarza Viadukt (8)*

Weinzettelwand (3)

Pollereswand Tunnel, Krauselklause (2)

Kalte Rinne Viadukt (12)*

Adlitzgraben Viadukt (3)

Haupttunnel (14)*

\section{Szczególne omówione miejsca}

Kapelle, Priesterwohnung, Schule (8)*

Arbeiterunterkünfte (7)*

Burg Klamm (7)

Schottwien (4)

Liechtensteinscher Landschaftsgarten (2)

Station Eichberg (2)

Opis krajobrazu wartościowany negatywnie (37)*

Opis krajobrazu wartościowany pozytywnie (69)*

Pozostałości po wysadzeniu skał, hałdy żwiru (13)*

Wypadki przy pracy (6)

17 Pojęcie Kunstbauten [użyte w oryginalnym tekście — przyp. thum.] określa wspólne pojęcie odnoszące się w dziedzinie budowy dróg i kolei do budowli inżynierskich, takich jak tunele czy wiadukty. 
W toku kodowania uwidoczniło się nagromadzenie poszczególnych kategorii, które później stały w centrum analizy ${ }^{18}$. Parafrazy odnoszą się ściśle do tekstów oryginalnych, redukując je do zwięzłych wypowiedzi. W kolejnym kroku parafrazy poddano generalizacji. Zwięzłe wypowiedzi podległy w procesie generalizacji transferowi z historycznego języka przewodników do języka odpowiedniego dla kontekstu badawczego. W trakcie redukcji skreślono wreszcie powtarzające się wypowiedzi.

W celu dokonania analizy opartej na kategoriach zgeneralizowane wypowiedzi zostały ponownie przyporządkowane obu grupom czasowym: przewodników dotyczących budowy i przewodników dotyczących kolei. Opisy podróży z perspektywy pociągu zostały osobno uwzględnione w analizie. Wyniki zostały opisane, a kluczowe wypowiedzi rozpracowane wedle kategorii. Wreszcie wyniki poszczególnych kategorii powiązano i poddano krytycznej refleksji.

\section{Wyniki \\ Rozmaite wspaniałości ruchomych panoram}

Trudno znaleźć opis krajobrazu obfitujący bardziej w pozytywne przedstawienia niż ten dotyczący miejsca budowy linii kolejowej Semmering. Już w okresie budowy region ten znaczyły soczyste łąki, strumienie, młyny, fabryki, wsie i zagrody. Spoglądało się na panoramę uroczych krajobrazów, na krainę żyzną i urodzajną. Las był tu zieleńszy, a niebo bardziej błękitne niż na nizinach. Malowniczo, jakby przez ogród, ciągnęła się droga do Włoch przez Semmering. Rajski krajobraz układał się jak rozwinięta mapa. Imponujące partie skalne wywierały olbrzymie wrażenie w alpejskiej scenerii. Znajdująca się w toku budowy trasa kolejowa, ale i sama budowa opisywane były jako coś cudownego i potężnego. Z miejsc budowy wiaduktów rozciągały się urocze widoki w głąb doliny ${ }^{19}$. Podkreślano wspaniałość małej miejscowości Klamm z zamkiem, który jak orle gniazdo tkwił zawieszony w skalnej ścianie. Będąc tam na górze, można było wpaść w zachwyt, przyglądając się budowie ${ }^{20}$. Podjęcie wyzwania, jakim było wybudowanie kolei na tej wysokości, przedstawiano jako najbardziej pamiętne wydarzenie w historii tego miejsca. Wielkość, piękno, zapał i bezpieczeństwo związane z całokształtem budowy ukazywały doskonałość triumfu ludzkiej inteligencji ${ }^{21}$.

$\mathrm{Z}$ radością pomyśli każdy oglądający tę imponującą budowlę o swej ojczyźnie, - gdyż ożyje w nim poczucie, że żadna kolej świata nie przedstawia sobą czegoś większego i piękniejszego! ${ }^{22}$

Podkreślano wobec widoku na gotową kolej krótki czas jej budowy i porównywano ją z największymi dziełami sztuki budowlanej.

18 Uwzględnione w dalszym badaniu kategorie zostały na liście oznaczone gwiazdką.

19 A. Schuhmacher, Der Führer über den Semmering (1852).

20 F.C. Weidmann, op. cit.

21 A. Schuhmacher, Der Führer über den Semmering (1853).

22 Ibidem, s. 39. 
Godnym podziwu jest fakt, że ta olbrzymia budowla, mogąca stać w jednym szeregu z najwspanialszymi budowlami rzymskimi, została ukończona w ciągu 6 lat $^{23}$.

Linia kolejowa na Semmering jest jedynym w swoim rodzaju na tym boskim świecie olbrzymim dziełem ludzkiego konceptu i siły woli, tak jak odwieczna świątynia Karnak czy piramidy w Gizie... ${ }^{24}$

Z detalami opisywano wspaniały widok w czasie podróży, który pozwalał podziwiać cudowną panoramę i wywierające ogromne wrażenie szorstkie, poprzerzynane szczelinami ściany skalne doliny Adlitzgraben. Nawet jeśli uwagę podróżnych angażowały następujące po sobie budowle kolejowe, to z całą pewnością była ona poświęcana również niezwykle pięknemu krajobrazowi zdobiącemu trasę ${ }^{25}$. Dzięki poprowadzeniu trasy licznymi zakrętami widać było, jak jest imponująca i pełna artyzmu. W ten sposób śmiałość, z jaką stworzono tę linię kolejową, mogła wryć się w pamięć bardziej niż w innych przypadkach ${ }^{26}$. Widok z trasy na Semmering ku wsiom i fabrykom w dolinach postrzegano jako malownicze i powabne, a pokryte śniegiem góry w tle jako majestatyczne. $\mathrm{Z}$ chwili na chwilę jazda stawała się coraz piękniejsza dzięki różnorodności trasy. Za oknami pociągu przesuwała się wspaniałość wielorakich ruchomych panoram. W momencie przejazdu przez najwyżej położony punkt kolejowy świata podróżnych przenikała świadomość czegoś podniosłego, głęboko poruszającego ${ }^{27}$. Z perspektywy pociągu tematyzowano prędkość i dynamiczny ruch spojrzenia. Malownicze spojrzenia wstecz na jedyne w swoim rodzaju budowle inżynierskie i na góry w tle przeplatały się z sobą ${ }^{28}$.

\section{Wbrew kolosalnemu oporowi gór}

Wysokość, na której budowano linię kolejową, postrzegana była w czasie tejże budowy jako straszna i wstrząsająca.

Uczucie tajemnego lęku przenikało tu chyba każdego widza ${ }^{29}$.

Ingerencja we wspaniały, wzniosły świat gór opisywana była jako widoczny gwałt. Kolej zbudowano wbrew kolosalnemu oporowi gó ${ }^{30}$. Dolina Adlitzgraben, rozsławiana wcześniej ze względu na swą romantyczną naturę, z powodu budowy kolei stała się jednym z najdziwniejszych miejsc monarchii. Opisywano

23 W.A. Julius, op. cit., s. 19.

24 A. Mandl, J.G. Seidl, op. cit., s. 82.

25 F.C. Weidmann, T. Gettinger, op. cit.

26 A. Mandl, J.G. Seidl, op. cit.

27 W.A. Julius, op. cit.

28 R. Hellbach, op. cit.

29 A. Schuhmacher, Der Führer über den Semmering (1853), s. 25.

30 Ibidem, s. 36. 
śmiało wytyczoną ponad pionowymi urwiskami i olbrzymimi skałami, wysoko ponad doliną Adlitzgraben, trasę kolei.

Z niejakim lękiem zmierzyłem wysokość, na jakiej wydrążone w murze skalnym tunele wyznaczają przyszłą trasę kolei! — Wstrząsająca myśl!! ${ }^{31}$

Dzika i przekorna natura tworzyła przeszkodę, którą trzeba było pokonać przy budowie kolei. Potężną ową ingerencję opisywano w sposób wywierający mocne wrażenie.

Sztuka również tu wiele dokonała, a widok wspaniałego świata gór, którym wydarła trasę dla kolei parowej, jest wręcz wzniosły, lecz nigdzie nie musiała ona ingerować, zadając tak widoczny gwałt, nigdzie nie walczyła z tak kolosalnym oporem ${ }^{32}$.

Wrażenie, które na podróżnych robiła budowa, zasadniczo powstało pod wpływem widoku materiału z odstrzałów.

Romantyczny żleb skalny... został w toku prowadzonych przy (ścianie skalnej) Weinzettelwand odstrzałów zasypany żwirem i osuwającym się materiałem skalnym ${ }^{33}$.

Odstrzały powodowały drżenie całych gór, w powietrzu unosił się dym. Góry utraciły swoją nieskończenie trwałą moc i zdawały się tylko prowizoryczne ${ }^{34}$. Zdawało się, jak gdyby ludzie przesuwali góry, $\mathrm{z}$ wielkim trudem wydzierając każdy metr przestrzeni ${ }^{35}$.

W przewodnikach dotyczących wybudowanej kolei opisy gwałtu i niepokornej natury ustępują poruszającemu i ujmującemu przeżywaniu krajobrazu. Przez stromo opadające żleby z przewieszonymi skałami, straszliwe otchłanie i groty wytyczono linię kolei. W trakcie jazdy w nocnej ciemności skały ukazywały się upiornie w mgnieniu świateł lokomotywy, z domów w dolinie zamigotało czasem światło, podróżnych przenikał lęk aż do szpiku kości, a ciało przebiegały dresz$\mathrm{cze}^{36}$. Dreszcz grozy wywoływały grupy skalne wiaduktu Kalte Rinne i skalisty żleb Krauselklause ${ }^{37}$. Wielokrotnie opisywano wywołujący zawrót głowy widok $\mathrm{z}$ pociągu w leżące głęboko doliny ${ }^{38}$. Wyglądając przez okno pociągu, niemal już całkiem nie zwracano uwagi na wielkie ruchy ziemi czy też hałdy żwiru ${ }^{39}$.

\footnotetext{
31 Ibidem.

32 Ibidem, s. 38.

33 F.C. Weidmann, op. cit., s. 89.

34 A. Schuhmacher, Der Führer über den Semmering (1852).

35 A. Schuhmacher, Der Führer über den Semmering (1853).

36 A. Mandl, J.G. Seidl, op. cit.

37 W.A. Julius, op. cit.

38 R. Hellbach, op. cit.

39 F.C. Weidmann, T. Gettinger, op. cit.
} 


\section{Aktywne życie w koloniach robotniczych}

Robotnicy zatrudnieni przy budowie kolei Semmering byli zakwaterowani w różnych miejscach budowy, które opisywano przede wszystkim w przewodnikach dotyczących budowy kolei. $\mathrm{Z}$ podziwem oglądano noclegowiska $\mathrm{w}$ jaskiniach i drewnianych chatach wśród ska ${ }^{40}$. Wielkie kolonie robotnicze przedsiębiorców budowlanych były trudnymi do przeoczenia elementami krajobrazu charakteryzującymi się ożywionym działaniem ${ }^{41}$.

A jednak jeszcze powyżej linii kolejowej toczy się życie! Dostrzec można mieszkania ludzkie — w grotach — w małych drewnianych chatach, które wiatr nacierający na ścianę skalną w każdej chwili może zmieść — tu i tam w zagłębieniach skał poruszają się ludzkie postaci. Są to robotnicy, a te chaty $i$ groty to „mieszkania!’’2

Cztery lata po ukończeniu budowy wspominano jeszcze mocno zaludnione kolonie.

Tak zwana kolonia Fleischmanna ze swymi licznymi budynkami mieszkalnymi, biurami, warsztatami i setkami po części jednopiętrowych chat sama w sobie była okazałą i silnie zaludnioną miejscowośćc ${ }^{43}$.

Kaplica wraz z domem księdza, a także zaimprowizowana szkoła były budynkami postawionymi dla robotników i zauważanymi ze względu na swoje szczególne funkcje. Ich położenie na łące przy skraju lasu oraz wystrój w stylu szwajcarskim ze specyficznym dachem i sposobem malowania wyróżniały je spośród prostych domów robotników, przyciągając uwagę zwiedzających budowę kolei $^{44}$. Kaplica stała jeszcze po zakończeniu budowy kolei Semmering ${ }^{45}$. Później została rozebrana.

\section{Godny przedsionek — wiadukt Schwarza}

Już w przewodnikach dotyczących budowy wiadukt Schwarza w Payerbach przedstawiano jako jedną z najwspanialszych budowli kolei Semmering. Budowa była już bardzo zaawansowana, tak więc można było wiadukt szczegółowo opisać ${ }^{46}$. Olbrzymie wrażenie, jakie to mistrzowskie dzieło wywierało na podróżnych, było przeciwstawiane sile natury reprezentowanej przez rzekę

40 F.C. Weidmann, op. cit.

41 A. Schuhmacher, Der Führer über den Semmering (1852).

42 Ibidem, s. 36.

43 W.A. Julius, op. cit., s. 29.

44 A. Schuhmacher, Der Führer über den Semmering (1852).

45 W.A. Julius, op. cit.

46 A. Schuhmacher, Der Führer über den Semmering (1853). 
Schwarza, która mogła osiągnąć przy wysokich stanach wód niewiarygodną siłę i szerokość 47 .

$\mathrm{W}$ opisach dotyczących wybudowanej kolei wiadukt zestawiano z wielkimi dziełami sztuki budowlanej, podkreślano przy tym jego robiącą wrażenie wielkość.

Wśród licznych obiektów budowlanych wiadukt rozpięty nad Doliną Schwarza jest najdłuższym ze wszystkich tu występujących, godnym przedsionkiem tej gigantycznej budowli ${ }^{48}$.

[...] widziany od północy wydaje się segmentem potężnego amfiteatru, z przeciwnej zaś strony bliskie Payerbach ze swym kościołem służy za tło olbrzymich różnic; zmieściłby się on cały wraz ze swą wieżą pod jednym z powietrznych sklepień wiaduktu ${ }^{49}$.

Prawdziwie czarowny widok na dolinę rzeki Schwarza dopiero z wiaduktu robił tak wielkie wrażenie ${ }^{50}$. Na obie strony rozciągały się najcudniejsze widoki, a spojrzenie przez łuki wiaduktu ukazywało piękne, jakby ujęte w kamienne ramy, krajobrazy ${ }^{51}$.

\section{Zdziwienie na granicy dreszczu — wiadukt Kalte Rinne}

Przewodniki dotyczące budowy kolei wyraźnie ukazują postępy budowy wiaduktu Kalte Rinne. W 1852 roku wyrósł do połowy wysokości pierwszy rząd filarów, a po rusztowaniach można było już określić wysokość pierwszego łuku. Niezgodności pewnej opublikowanej ilustracji, która przedstawiała wiadukt fałszywie jako trzykondygnacyjny oraz opisywała go jako most nad Atlitz (sic!), zostały zauważone i poprawione ${ }^{52}$. Już rok później gotowa była pierwsza kondygnacja, a w fazie budowy znajdował się drugi rząd filarów, na którym ostatecznie ułożono tory ${ }^{53}$.

[...] już niedaleko od wiaduktu Talachini, którego pierwszy rząd filarów wznosi się już do połowy wysokości ${ }^{54}$.

[...] już niedaleko od Wiaduktu Talachini, którego pierwszy rząd filarów jest już zwieńczony łukiem, a drugi wznosi się na połowę wysokości ${ }^{55}$.

\footnotetext{
47 Ibidem.

48 A. Mandl, J.G. Seidl, op. cit., s. 92.

49 Ibidem, s. 93.

50 Ibidem.

51 W.A. Julius, op. cit.

52 A. Schuhmacher, Der Führer über den Semmering (1852).

53 A. Schuhmacher, Der Führer über den Semmering (1853).

54 A. Schuhmacher, Der Führer über den Semmering (1852), s. 39.

55 A. Schuhmacher, Der Führer über den Semmering (1853), s. 29.
} 
Filary wiaduktu Kalte Rinne i ich zwieńczenia na tle zalesionych gór były odbierane jako bardzo malownicze. Opisywano odczucie wielkiego majestatu wzmacniane samotnością okolicy.

Problem został rozwiązany dzięki wspaniałej budowli, której smukłe filary i sklepienie, już same w sobie malownicze, wyróżniają się na tle leżących w tyle zalesionych gór ${ }^{56}$.

Wiadukt Kalte Rinne uchodził za najśmielszy na trasie. Przy spojrzeniu $\mathrm{z}$ doliny na wiadukt, przez który pędził właśnie z zawrotną prędkością pociąg, szczególnie mocno odczuwało się graniczący z dreszczem przerażenia podziw ${ }^{57}$. Gotowy wiadukt opisywany był poetycko i z wielkim uznaniem.

\section{Podróż do podziemi — Tunel Główny}

Tunel Główny jest najdłuższym tunelem kolei Semmering, już w czasie budowy opisywano niezmordowaną nad nim pracę. Zwiedzanie go odradzano ze względu na zimno i wilgoć panujące we wnętrzu ${ }^{58}$.

Zwiedzania tunelu nie polecam mniej zahartowanym naturom, szczególnie jeśli rozgrzane są szybkim marszem czy może słonecznymi promieniami letniego popołudnia ${ }^{59}$.

W pierwszych latach działania kolei w przewodnikach znajduje się zalecenia odnośnie do jego zwiedzania:

Tu podróżni zwykle wysiadają, aby oddać się podziwianiu otaczających ich cudów oraz, tak daleko jak dozwolone, zwiedzić tunel na piechotę... ${ }^{60}$

Jazda tunelem opisywana była jako podróż w świat podziemny. Ogłuszający łoskot lokomotywy parowej, ciemność i migające z boku lampy przypominające robaczki świętojańskie więziły myśl i napawały uczuciem strachu. Przy powtarzających się przejazdach tunel w dużym stopniu tracił swój odstraszający charakter ${ }^{61}$.

\section{Wnioski}

Budowa kolei oznaczała dla przełęczy Semmering połowy XIX wieku olbrzymie zmiany w zagospodarowaniu krajobrazu, które przerosły wszelką miarę dotychczasowych ingerencji i procesów w tym regionie. W łagodny krajobraz

56 A. Mandl, J.G. Seidl, op. cit., s. 96.

57 Ibidem.

58 A. Schuhmacher, Der Führer über den Semmering (1852).

59 Ibidem, s. 42.

60 W.A. Julius, op. cit.

${ }^{61}$ A. Mandl, J.G. Seidl, op. cit. 
wprowadzono projekt związany z infrastrukturą. To tu po raz pierwszy pokonano Alpy koleją żelazną — kolej na Semmering stała się pomnikiem zwycięstwa techniki nad naturą.

Tu dokonało się zwycięstwo nad potężnym, zwartym łańcuchem Alp ${ }^{62}$.

Jakościowa analiza treści badanych przewodników z lat 1852-1873 ukazuje w wyraźny sposób różne płaszczyzny postrzegania. W nader pozytywnych, poetyckich sformułowaniach opisany został krajobraz, w którym budowano kolej. Wspaniałość wyrażała się $\mathrm{w}$ pionierskim charakterze przedsięwzięcia, tak że w końcu kolej Semmering została zrównana z cudami świata. Wartościujące negatywnie opisy są w kontekście przewodników szczególnie godne uwagi, gdyż mogą być odczytywane jako krytyczna refleksja dotycząca zmienionej sytuacji. Opis warunków naturalnych ma budzić szacunek oraz wyrażać lęk wobec nieznanej olbrzymiej budowli. Opór stawiony tej dzikiej przyrodzie zmienił się ostatecznie w zwycięstwo. Miast ubolewać nad zniszczeniem przyrody, świętowano zwycięstwo nad nią człowieka tudzież techniki. Po ukończeniu budowy opisy warunków życia robotników i robotnic zostały zastąpione historiami sukcesu inżynierów. Porównując przewodniki dotyczące budowy i te na temat gotowej linii kolejowej, można wyraźnie wyczytać postęp budowlany. Nawet jeśli ingerencje w krajobraz w czasie budowy kolei opisywane były szczególnie drastycznie, to budowa ta nie była postrzegana jako zagrożenie czy wręcz zniszczenie krajobrazu. Wspaniałość tego przedsięwzięcia budowlanego od początku nie była podawana w wątpliwość.

Przewodniki umożliwiają prześledzenie postrzegania tej, wówczas nowej, przemiany krajobrazu, otwierają zróżnicowane spojrzenie na krajobraz. Jak to ogólnie przyjęte, tak i badane przewodniki zawierają informacje o miejscach wartych zwiedzenia. I tutaj na pierwszy plan wysuwają się pozytywne opisy. Reprezentują one specyficzny wycinek recepcji, w której mało jest miejsca na refleksję lub krytykę. Dokładna weryfikacja doniesień z gazet codziennych mogłaby umożliwić spojrzenie $\mathrm{z}$ innej strony na ten temat.

Budowa kolei Semmering do dziś jest wyrazem działania kulturowego tamtych czasów. Na pierwszy plan jej recepcji wysuwa się harmonijne i subtelne wkomponowanie trasy w topografię. Doskonałość budowli inżynierskich uważano za ubogacające uzupełnienie krajobrazu. Wytyczona trasa wraz z budowlami inżynierskimi są świadectwem udanej syntezy przyrody, infrastruktury i kształtowania krajobrazu. Kształtowanie to umożliwia dialog techniki i natury, wzbogacając krajobraz.

Z języka niemieckiego przełożyta Monika Witt

62 Ibidem, s. 99. 